\author{
M.A. Urazgalieva ${ }^{1, *}$, N.K. Kalaganova ${ }^{2}$, O.I. Lygina ${ }^{3}$, I.A. Rykova ${ }^{4}$ \\ ${ }^{1,2,3}$ Baishev University, Aktobe \\ ${ }^{4}$ Oryol state University of Economics and trade, Orel \\ 1'urazgaliyevama@mail.ru, ${ }^{2}$ kalaganova.n.k@mail.ru, \\ 3ygina_olga@mail.ru, ${ }^{4}$ olegnashevce-orel@yandex.ru \\ ${ }^{1}$ https://orcid.org/0000-0001-5322-9392, ${ }^{2}$ https://orcid.org/0000-0002-9031-2686, \\ ${ }^{3}$ https://orcid.org/0000-0002-8898-8476, ${ }^{4}$ https://orcid.org/0000-0002-5018-1984
}

\title{
Mechanisms for supporting "Green Finance" in the world practice and in Kazakhstan
}

\begin{abstract}
Object: To study the necessity of strengthen the role of "Green" financing in the economy of Kazakhstan, the most successful examples of financing and implementation of tools to support "Green" projects in more developed countries. Accordingly, the subject of the study is the financing of the "Green" economy in the world practice and in Kazakhstan.

Methods: Abstract-logical, system analysis, comparative analysis.

Findings: As a result of the study, development state of "Green" financing in Kazakhstan is assessed and the experiences of advanced countries are identified.

Thus, in the course of analysis more advanced countries were identified, such as China, Korea, the United Kingdom, Canada and others, which have made some progress in the release of " Green tools implementation of electricity production from renewable sources, recycling of household waste and reduction of biodegradable landfills and formation of targeted environmental investment funds, etc. Obtained results indicate that Kazakhstan has not sufficiently addressed the aspects of economy related to sources of "Green" financing that contribute preservation of environmental quality in conditions of financial resources shortage and bringing it in line with the principles of sustainable development of the country. Also, the issue of "Green economy" is not sufficiently activated, which covers such categories as "Green" economy, "Green" credit, "Green" thinking, etc.

The reached conclusions outlined in the study framework are in general nature, we simply set the task-to find out the current situation on this issue and continue to rethink the modern concepts of scientific approaches in this area.

Conclusions: The development of Green finance in Kazakhstan and government support the Green incentives should be aimed at ensuring the sustainable development of the Green economy through:

- creating an effective mechanism for implementing "Green" finance;

- formation of management system for development of "Green" finance and its consolidation in legislative and regulatory acts.
\end{abstract}

Keywords: «Green» economy, «Green financing», «Green investments», «Green projects», «Green credit», «Green bonds», etc.

\section{Introduction}

In the world, for all countries, one of the components of the competitiveness category is considered to be the environmental aspect, which sets a new format for international cooperation on the implementation of «Green» financial instruments and most countries are actively involved in the process and support the development of the «Green» Finance market in the national interest.

Therefore, acceptance of timely decisions to ensure a quality development - in contrast to solutions of catch-up development. In addition, «Green» financing is «a window of opportunity in the modern world, which implies a qualitatively new development of the national financial market». (Greenbelarus.info, 2019)

\section{Literature Review}

According to the source «Green Finance: there is a chance not to be late», the authors adopted a number of statements, such as:

- theembeddedness of the Green component in the financial system of economic entities and the country as a whole, and this should be supported by state approaches;

- the implementation of Green Finance means adhering to three criteria. these are Green loans, Green bonds, Green banks and Green funds, i.e. we are talking about the use of modern financial instruments of the circular economy, which in the future will find justification in terms of their active viability.

\footnotetext{
${ }^{*}$ Corresponding author.

E-mail address: urazgaliyevama@mail.ru
} 
In the materials of the G20 summit in China (Hangzhou) in the direction: Green light for Green Finance (2016, September, 28), attention is paid to the concept, goals and scope of financing for the "Green economy», tools and recommendations for overcoming existing challenges in various countries are considered, while emphasizing that «China is becoming a world leader and Directives have been developed for the formation of a national Green Finance mechanism, which provides for attracting private investment in the Green economy, since funding from state sources is estimated by experts to be only $15 \%$ »

The program «Greening the economy in the Eastern partnership countries» offers recognized ways to reform public policy, corporate strategies, and public awareness of environmental consumers. (EaPGREEN, 2014)

In a number of countries, one of the most pressing issues is ensuring the quality of life of the population, and many States have declared their commitment to the goal of developing a «Green economy» that ensures the implementation of the concept of sustainable development. The usefulness of this publication is that all interested parties can use this document as a reference guide.

The article entitled «The financial mechanism for providing investment lending to the economy of Ukraine with the participation of international financial institutions» (Bulletin of NAS RK No. 6. 2019), helped to support the understanding of problems with a chronic nature, in particular, in environmental issues that require significant financial resources (long-term investments), including with the participation of international financial institutions (IFIs). This practice also takes place in Kazakhstan through the UNDP and investment efficiency from the implementation of «Green projects» of IFIs is currently in the formation stage, so it is not yet possible to give a sufficient assessment, although some experts note positive effects.

In the materials «His Majesty The government. Updated information on the design of the Green Investment Bank» (investment Bank report, 2011) presents the experience of this state's commitment to environmental damage and sets out the vision of a new and strong institution - the world's first dedicated Green investment Bank.

The author also demonstrates the practice of the Offshore wind energy Fund (GIB), whose institutional investors are life insurance companies, pension funds and state welfare funds. the author examines the effective aspects of the GIB Fund's existence in order to state his vision of the continuity of the Fund's experience in other countries (report of the Green investment Bank, 2014).

Working with the materials of the research on the topic «A Green Economy for Canada: allowed the authors to make sure that there is no consensus on the concept of "Green economy» and the opinions of many participants based on the conference materials are aimed at optimizing communication efforts. there is a reasonable national dialogue between States on the issue of environmental protection and, in particular, the issue of financing environmental programs (Canadian Institute for Environmental Law and PolicyCIELAP,2011)

The study of the Ontario budget according to the document made it possible to identify effective practices in this province of Canada for issuing "Green bonds» and financing relevant environmental projects.

According to UNEP sources. Review of the national strategy of the Republic of Korea for Green growth and an article entitled "System architecture for effective Green Finance in Korea, the Korean economy" found that Korea considers the "Green economy" and "Green growth" as a unique basis for its country's development and recognized it as part of the national strategy. In addition, the author claims that countries where Green technologies do not have a reputation can be considered risky. The author considers the Korean experience in the application of "Green technologies" as an object for continuity in Kazakhstan in accordance with the national capabilities of the country. System architecture for efficient Green Finance in Korea, ((OECD strategy 2011, Kim Hyun Tae. 2010)

The process of creating and establishing the AIFC's activities is necessary in the context of the needs of developing the country's Green economy, capital market and financial services, and the "Green" component is supported as a Strategy on the AIFC site (Bulletin of NAS RK No. 5, 2019, 191-198)

By sources: Internet resource: IA "BNews.kz" and the reporting material of IA Strategy 2050.kz tracks the development of the Green economy and what progress Kazakhstan has so far.

The Internet resource "Green bonds for Green business" addresses the issue of risk management, which involves banks taking into account environmental risks in credit analysis in order to avoid reputational risk or financial losses ( Kapital.kz, 2020).

Despite a number of existing positive aspects, many researchers identified and constraints development of "Green economy" is underdeveloped in the field of the environment, the uncertainty of the investors com- 
ponent to "Green" the measurement problem "Green growth", the preference of the banking sector, firms large and dirty (Rakov I. D.2017)

A review and comparison of individual advanced approaches from various literature sources allowed us to identify effective "Green" technologies, ensuring "Green" growth as part of national strategy, issuing "Green" bonds, forming "Green" funds, however, our state at the present stage of its development does not have enough national capabilities to implement the best practices of "Green" financing.

Now in the market of "Green" services mainly operate IFCA-"Astana", which is engaged in providing financial services of international level, i.e. at the macro level, therefore implementation issue of "Green" projects of small and medium business was an outsider and it's enough to note that the development of "Green" potential depends on the ability of sustainable development of the country.

In the list of used sources, the authors mainly considered and disclosed practical approaches from foreign sources, as well as domestic literature on this topic or convincing examples of practice on "Green" economy with all components ("Green" financing. "Green" investments, etc.) it turned out to be very problematic due to the lack or insufficient attention of economic scientists to disclosure of financing problems of "Green projects" at meso-and mico-level.

In our opinion the "Green" economy is spelled out in different ways in the strategic documents of Kazakhstan, somewhere it is declared without explaining how to implement it, in the number of documents on the development strategy of companies posted on websites, only elements are reflected, if you put them together, then a fragmentary strategy is formed in terms of the implementation of the category under study.

In general, it should be noted that there is practically no scientific work in Kazakhstan on the stages of development and creation of the "Green" economy. In this regard, in this research, we have to limit ourselves only to the results of comparative analysis and abstract-logical conclusions about formation of theoretical approaches to implementation of opportunities for" Green " financing.

\section{Methods}

In the study we applied the empirical method of investigation (description. comparison); general logical methods (analysis. abstraction. conclusions. a systematic approach), which made it possible to update the urgent need, seriousness and priority of lending to environmental projects around the world and to take all possible measures to activate "Green" long-term financing instruments in Kazakhstan.

\section{Results}

If we consider the global experience of environmental Finance, then China is the leader in the activity of issuing "Green" bonds, and in 2016 the circulation was the highest in the world. The development of the Green bond market has contributed to the opening of new financing channels for Green enterprises and projects. [G20 summit,(2019)].

Many countries are interested in studying the experience of the Eastern partnership (EAP) countries) The European community (EU), where an important source of long - term financing for "Green" investments is the credit lines of international financial institutions (IFIs) in the field of energy and resource efficiency. The IFI consists of: The European Bank for reconstruction and development (EBRD), the international Finance Corporation, the European investment Bank, the world Bank (IBRD), the Asian development Bank, KfW, the Austrian development Bank, and the Northern environmental Finance Corporation (NEFCO). [Report by OECD, 2014, 141-151, Panteleeva N et al., Bulletin of NAS RK №6. 2019, 141 to 153]

In addition to environmental financing through banks, EAP countries use other multilateral instruments, including the Green Fund for growth, the Global climate partnership Fund, and the E5P Fund.

The experience of using mechanisms to support Green Finance in developed countries is interesting. for example, the UK's environmental ambitions were as follows: to produce $15 \%$ of all energy from renewable sources, to recycle $50 \%$ of household waste by 2020 , and to reduce the landfill of biodegradable urban waste by $35 \%$ by 2020 compared to 1995 (EU Waste Framework Directive, Investment bank report, 2011, 2014)

In 2012, the Green investment Bank (GIB), created on the initiative of the government of England, identified barriers to weak investment flows in" Green " projects and one of the most serious among them is the difficulty of attracting institutional investors to a large number of small low-carbon projects, which is inherent in the practice of many countries. The Bank (GIB) uses the following main tools to eliminate these barriers: loans and equity investments, financing through an investment Fund, and guarantees. In the UK, the financing of "Green" projects is supported by the British business Bank, whose clients-borrowers are primarily small and medium - sized businesses. 
In Korea, the President (Lee Myung-Bak) announced the implementation of the national strategy for "low-carbon "Green" growth" in November 2008, and according to the strategic plan for 2009-2013, expenditures were planned at the rate of $2 \%$ of GDP .

As part of the "Green" new deal, the Korean government has increased its focus on major construction projects, including the restoration of four major rivers, the construction of 1 million "Green" homes by 2020, high-speed Railways, and "Green" lending is provided through conventional commercial banks that use three schemes: direct lending, re-lending, and Deposit scheme. (UNEP Green Economy Initiative, 2015)

Features of the "Green "practice in Canada are that the problems of" Green " Finance are solved by the territorial and provincial governments. Based on a study by The Canadian Institute for Environmental Law and Policy (CIELAP) the factors that hinder the implementation of the "Green" economy and the influx of "Green" investments are identified, as such: lack of leadership positions of the "Green" economy at the Federal level, which creates unattractiveness for business; insufficient public understanding; tension and lack of coherence among and between stakeholders and the government.(Consulting: Carolyn Webb, Thomas C. Esakin,2011)

In this area, the most active province is Ontario, which was the first in Canada to issue Green bonds to Finance environmental projects (clean transport; energy conservation and energy efficiency; clean energy, forestry, agriculture, land management; adaptation and resilience to climate change). The Green Investment Fund is very effective. the main areas of funding are the construction of a network of fast charging stations for electric vehicles (us $\$ 20$ million), reduction of Greenhouse gas emissions and electricity costs (us $\$ 100$ million), support for the energy efficiency initiative for small and medium-sized enterprises (SMEs) (us $\$ 26$ million), and support for other initiatives

The Toronto Atmospheric Fund (TAF) and Tridel (a residential developer) launched an energy efficiency loan program (Green Condo Loan program) in 2005. The essence of the program was that the Fund provides credit for the gap between buyers who will have lower utility costs due to energy efficiency (by $25 \%$ or more), and builders who spent more money on the construction of "Green" buildings, etc. (Ontario Budget, 2016)

Analysis of the experience of developed countries has shown that market mechanisms, in contrast to government support measures, can not reorient the traditional economy to "Green" and this is due to the fact that "Green" projects, unlike conventional ones, have higher risks and a longer payback period. Therefore, only the measures of state support are able to address these market failure and to promote the business.

In Kazakhstan, the Astana international financial center (hereinafter referred to as the AIFC) is an ana$\log$ of the IFI from the experience of the Eastern partnership countries, which considers the "Green Finance" industry as one of its priorities. Getting into the essence of the concept of "Green Finance" it is necessary to understand that they mean financial resources that are intended for the implementation of projects aimed at reducing air pollution, reducing water, energy, heat, and so on. Although the term is interpreted in different ways, the basic idea is always to preserve the environment. The instruments of "Green Finance" are bonds, trading quotas for $\mathrm{CO} 2$ emissions, loans, Bank cards, mortgages and insurance, and others/ (Zhagyparova A. O. et al., 2019)

In the post-Soviet space, Kazakhstan is a leader in the transition to a Green economy. The environmental code was adopted in 2007, the concept of transition to a Green economy was adopted in 2013, and the Paris Convention was ratified in 2016. In the above-mentioned and other documents, the implementation of Kazakhstan's goals in the "Green" economy is set until 2050

Kazakhstan has been cooperating with the United Nations development Program (hereinafter referred to as UNDP) for more than seventeen years, which supports national partners to implement the concept of sustainable development of Kazakhstan until 2024. UNDP also supports the country's efforts to address global warming by promoting energy conservation, more economical use of water resources, and the mobilization of renewable energy sources, including wind power .(IA "BNews.kz, 2019, September, 12)

In 2016, UNDP launched four projects at the state level aimed at using "Green" technologies in desert and semi-desert regions, integrated use of reservoirs and sanitation in rural areas, as well as the construction of Greenhouses in the Northern regions of the country to diversify the market for fruit and vegetable products, the essence and directions of which are systematized in table 1. 
Table 1. Directions and results of the implementation of "Green" projects

\begin{tabular}{|l|l|}
\hline \multicolumn{1}{|c|}{ Projects } & \multicolumn{1}{c|}{ Goal and results of Green technology } \\
\hline Kyzylorda region & $\begin{array}{l}\text { 1 project: Returning desert and semi-desert regions to agriculture and using these zones } \\
\text { in agricultural activities by creating oasis irrigation, }\end{array}$ \\
\hline $\begin{array}{l}\text { Almaty region, } \\
\text { Ili district, Akshi village }\end{array}$ & $\begin{array}{l}\text { 2 project: Creation of "Green" infrastructure with the aim of solving the issues of water } \\
\text { disposal in the village, which is not available in the village }\end{array}$ \\
\hline Astana & $\begin{array}{l}\text { 3 project: Equipping Greenhouses with modern production technologies and using re- } \\
\text { newable energy, which will ensure the cultivation of organic and environmental products } \\
\text { in the northern regions, while there is no need to import them from the south. }\end{array}$ \\
\hline $\begin{array}{l}\text { Aktobe region, } \\
\text { Kargaly district, }\end{array}$ & $\begin{array}{l}\text { 4 project: The development of fisheries, ponds, Greenhouses, the installation of mini- } \\
\text { hydroelectric power stations for energy supply of water infrastructure, the creation of } \\
\text { recreational areas with the aim of making full use of inactive water infrastructure. } \\
\text { It should be noted that through public-private partnerships the development of inactive } \\
\text { water infrastructure can attract investment in the regions, be economically viable, i.e. } \\
\text { make a profit }\end{array}$ \\
\hline \multicolumn{2}{|l|}{ Note: Compiled by the authors on the Internet source } \\
\hline
\end{tabular}

The experience of some countries demonstrates mechanisms to support SMEs ' access to long-term lending by providing loan guarantees, subsidizing interest rates in order to activate loan portfolios, and this practice has become practiced in Kazakhstan.

We conducted a survey of the practice of "Green Finance" for the housing and utilities modernization project in Kazakhstan in 2017 through the UNDP. In the process of verbal interaction with colleagues, JSC "entrepreneurship development Fund "Damu" is found out that in 2018 only received 6 applications in 2019 32 applications and it should be noted from the words of the representatives of the Fund investors in the face of small and medium businesses are reluctant to or do not support the development of projects of modernization of the sectors of municipal heat and water supply, public and residential buildings, street and interior lighting, as traditionally focused on trade than on some "Green projects".

To date, in Kazakhstan and in the regions, the work of UNDP is obvious, which verifies the project and proves its technical viability, then the investor receives a "Green" certificate on the basis of which financing is provided through second-tier banks and a subsidy agreement is concluded. The Damu Foundation provides funds allocated by UNDP and a guarantee of $50 \%$ of the loan amount has been declared for the first recipients to attract them. As a result, the subsidy is expressed in a reduction of the interest rate- $10 \%$ on commercial loans and the main criterion for selecting projects under this program is to reduce energy consumption.

The study of the essence of "Green credit lines" showed that banks could demonstrate a reputation, attractiveness and competitive advantages, however, without the support of resources of international financial institutions (hereinafter referred to as IFIs), the introduction of "Green lending" is limited or not implemented at all.

When asked why banks are forced to work with international financial institutions on "Green lending" products, the study revealed the following:

- the lowest cost of funds offered under environmental credit lines by IFIs available to commercial banks, i.e. more preferential than in the case of other products;

- the term of Green lending is longer than the term of lending for other products, and for many local banks this is one of the most important factors.

- most credit lines are accompanied by the provision of some form of technical assistance to a local financial institution (funded by donors).

- loans from donors are provided in foreign currency and conditions remain more attractive. All four of the above points are available to local banks and this "Green Finance" scheme is also available in the Eastern partnership countries.

When visiting local commercial banks (Sberbank, Forte Bank, Halyk Bank, Alfa-Bank, and others), one name of an environmental credit product called UNDP was suggested in the list of credit products and it was not requested. The abbreviation itself is given to a client who is not aware of the declared program at the state level and does not know the decryption does not say anything, so they will never pay attention to this credit product. In addition, we are not offered an advertising booklet for this product, where you can find complete information with an emphasis on the attractive part of this product, i.e. credit institutions themselves have not yet sufficiently realized the essence and significance of the economic category "Green credit" for a civilized state and therefore do not support the issue of updating. 
During the conversation with credit managers, we found out the reasons for the insufficient demand for opening environmental credit lines, which are systematized in table 2.

Table 2. Results of the authors' visit to local banks in the region on the implementation of a joint project of UNDP, The government of the RK and the entrepreneurship Fund «Damu»

\begin{tabular}{|c|l|}
\hline № & \multicolumn{1}{|c|}{ Reasons for the absence or low level of demand for environmental credit product of banks } \\
\hline 1 & $\begin{array}{l}\text { The absence of advertising booklet and consultation on this product is not carried out, therefore, customers } \\
\text { are not sufficiently informed about environmentally friendly technologies and associated economic bene- } \\
\text { fits obtained after the implementation of environmental projects }\end{array}$ \\
\hline 2 & $\begin{array}{l}\text { Borrowers prioritize economic considerations rather than environmental considerations, and therefore } \\
\text { there is no desire to prepare environmental projects }\end{array}$ \\
\hline 3 & high transaction costs for the promotion and monitoring of projects; \\
\hline 4 & $\begin{array}{l}\text { insufficient level of awareness by mankind of the scale and global nature of environmental protection } \\
\text { problems, etc. }\end{array}$ \\
\hline Note: compiled by the authors based on the results of a conversation with employees of JSC «entrepreneurship Fund «Damu» \\
\hline
\end{tabular}

\section{Discussions}

Thus, each state has opportunity to thoroughly study the successive aspects of world practice and, if necessary, use them, but for this it is necessary to make sure, taking into account national capabilities, to support its state, to carefully fix them in regulatory and legislative acts only then we will be able to interest and attract business structures to implementation of the "Green economy".

In Kazakhstan mainly Green deal financing foreign banks such as the European Bank of reconstruction and development, the world Bank, the Eurasian development Bank, the Asian development Bank, therefore, also be necessary to increase the line of credit by domestic banks to provide financial support for environmental projects under the low interest rates, and also need to involve other instruments that are recognized in the world.

In general, this study was aimed at finding answers to the questions: is there really "Green" financing in the context of "Green" investments, how many companies provide "Green" financing, and others. However, in order to answer to these questions, there was a need for information that would characterize the activity of Kazakhstan's companies in field of financing "Green investment projects" at their own expense. But due to the lack of statistical, reporting data and in order to extract information confirming the implementation of "Green" investment projects by private investors, the official websites of subsoil users in Aktobe region were analyzed and the following picture was obtained: - confirmation of information was shown by $-2.7 \%$, companies that expressed their intentions to finance environmental protection measures- $10 \%$, companies that do not disclose information about financing on the websites $-72.5 \%$, etc. This leads to conclusion that the main source of funding today is the state.

\section{Conclusions}

New global trends include "Greening" of the economy and Kazakhstan does not remain indifferent to this phenomenon. Recently, the topic of "Green" Finance deserves special attention, and stakeholders are discussing the relevance of "Green" Finance tools and the effectiveness of practical approaches to this area. However, the lack of clear environmental signals and the small experience of the AIFC as a coordinating center lead to the fact that "Green" initiatives remain fragmented and do not favor the consistent development of "Green" Finance in Kazakhstan.

The vital need for the development of "Green" financing is fully understood by society, but the implementation of subsequent actions is still fully under discussion. Self-financing, which is practiced by subsoil users in Kazakhstan, is one of the directions of the market mechanism for supporting "Green" investments, but it is not widespread and is poorly developed.

The main reasons that hinder the development of "Green" financing in Kazakhstan are: disunity and uncoordinated actions of the parties involved; little experience of the single center - AIFC, which does not yet have a sufficient portfolio of "Green" projects; lack of opportunities to set relatively modest targets in terms of reducing GHG emissions; weak provision of "Green" instruments with standards, regulatory framework; passive behavior of commercial banks; insufficient awareness of institutional investors, such as pension funds, insurance funds, and national welfare funds, about the risks and profitability opportunities associated with Green financing, etc. 
Therefore, as customary in international practice to achieve successful results in the markets of "Green" financing, effective use of "Green" tools or platforms is necessary to ensure coordination among the stakeholders (Ministry of environmental protection as to the applicant's environmental problems, IFCA coordinator, commercial banks, institutional investors, financing, small and medium businesses-entities that develop "Green" projects, consumers - subjects receiving Green services, etc.) and environmental considerations should be integrated into the framework of public policy, i.e. the state should play a significant role in supporting the development of Green Finance, not the market.

\section{References}

Carolyn Webb \& Thomas C. Esakin. (2011). A Green Economy for Canada: Consulting with Canadians. Canadian Institute for Environmental Law and Policy. http://cielap.org/pdf/CIELAP_Green Economy.pdf

Global Green Growth institute. (2015). Korea's Green Growth Experience: Process, Outcomes and Lessons. Learned.Retrievedfrom https://www.Greengrowthknowledge.org/sites/default/files/downloads/resource/KoreasGreen- Growth-Experience_GGGI.pdf

GOV.UK (2011). H.M.Government. Update on the design of the Green Investment Bank. Retrieved from: https://www.gov.uk/government/ uploads/system/uploads/attachment_data/file/ 31825/11-917-update -designGreen-investment-bank.pdf

Green financing: there is a chance not to be late. (2019) Eurasian Development Bank. Retrieved from: https://eabr.org/press/news/zelyenoe-finansirovanie-est-shans-ne-opozdat

Green Investment Bank Commission.( 2010) Unlocking investment to deliver Britain's low carbon future, Report by the Green Investment Bank Commission. Retrieved from https://www.e3g.org/wpcontent/uploads/Unlocking_investment_to_deliver_Britains_low_carbon_future_-_Green_Investment_Bank_ Commission_Report_June_2010.pdf

Khudyakova L.S. (2016). G20 Summit:Green Light for Green Finance,IMEMO RAN https: //www.imemo.ru/news/events/text/sammit-bolyshoy-dvadtsatki-zeleniy-svet-zelenomu-finansirovaniyu?ret=640

Kim Hyoung-tae. (2011). System Architecture for Effective Green Finance in Korea. Korea's Economy, 27, 18-24

OECD. (2015). Policy perspectives Leveraging innovative public finance to scale up low-carboninvestment. Retrieved from: http://www.Greeninvestmentbank.com/ media/25360/ar14-web- version -v2-final.pdf.

Panteleva, N., Mishhenko, S., \& Panteleva, K. (2019). Finansovyj mehanizm predostavlenija investicionnogo kreditovanija $\mathrm{v}$ jekonomike Ukrainy s uchastiem mezhdunarodnyh finansovyh institutov ["Financial mechanism for the provision of investment lending in Ukraine's economy with the participation of international Finance"]. Zhurnal Nan Rk. - NAC RK Journal, 6, 141-151 [in Russian].

Pokidaev D. (2019). UNDP approved support for 94 projects of modernization of housing and communal services in Kazakhstan. Italics. Retrieved from https://kursiv.kz/news/ekonomika/2019-09/proon-odobrila-podderzhku-94proektov-modernizacii-zhkkh-v-kazakhstane

Rakov, I.D. (2017). Mehanizmy podderzhki finansirovanija «zelenyh» proektov: opyt stran // Aktual'nye problemy jekonomiki i prava [Mechanisms for supporting the financing of "Green" projects: the experience of countries // Actual problems of Economics and law]. T. 11, No. 2. 67-82. DOI: http://dx.doi.org/10.21202/ 1993-047X.11 [in Russian].

Taxes in Kazakhstan. (2019). How Green finance will work in Kazakhstan. https://nalogikz.kz/docs/kak-budut-rabotatzelenye-finansy-v-k.html

William Francis Morneau, P.C., M.P. Minister of Finance (2016, March 22). Growing the middle class. Retrieved from: https://www.budget.gc.ca/2016/docs/plan/budget2016-en.pdf

Zhagyparova, A.O., Sembieva, L.M., Tahanova, M., \& Karpickaja, M.E. (2019). MFCA v vyrabotke mehanizmov «zelenogo finansirovanija dlja modernizacii kazahstanskoj jekonomiki [AIFC in developing mechanisms for" Green financing for the modernization of the Kazakh economy]. Zhurnal Vestnik Nacional'noj Akademii nauk Kazakhstana - Journal Bulletin of the national Academy of Sciences of Kazakhstan, 191-199 [in Russian].

Zhandybaev, K. (2018). Kak razvivaetsya «zelenaya» e'konomika v Kazakhstane [How the «Green economy» is developing in Kazakhstan] STRATEGY 2050 is an analytical and review portal. Retrieved from: https://strategy2050.kz/ru/news/51441/ [in Russian].

\section{М.А. Уразгалиева, Н.К. Калаганова, О.И. Лыгина, И.А. Рыкова}

\section{Әлемдік практикада және Қазақстанда «жасыл» қаржыландыруды қолдау тетіктері}

\section{Aңдаmna:}

Maқ̧саты: Қазақстан экономикасында «жасыл» қаржыландырудың рөлін күшейту қажеттілігі мәселесін зерттеу, неғұрлым дамыған елдердің «жасыл» жобаларын қаржыландыру мен қолдау құралдарын іске асырудың табысты мысалдарын зерделеу. Тиісінше, зерттеу пәні әлемдік тәжірибеде және Қазақстанда «жасыл» экономиканы қаржыландыру болып табылады.

Әдісі: Дерексіз-логикалық, жүйелік талдау, салыстырмалы талдау. 
Kорытынды: Зерттеу нәтижесінде Қазақстандағы «жасыл» қаржыландырудың даму жағдайы бағаланды, онда бұл мәселе жаһандық ауқымдағы негізгі позиция ретінде қаралды.

Осылайша, талдау барысында Қытай сияқты дамыған елдер анықталды. Корея, Ұлыбритания, Канада және басқалары «жаңартылатын көздер», тұрмыстық қалдықтарды қайта өңдеу және биологиялық ыдырайтын полигондарды азайту және атаулы инвестициялық экологиялық қорларды қалыптастыру және т. б. арқылы электр энергиясын өндіруді жүзеге асырудың жасыл құралдарын шығаруда белгілі бір жетістіктерге жетті.

Алынған нәтижелер бүгінгі күнге дейін Қазақстанда қаржы ресурстарының тапшылығы жағдайында қоршаған ортаның сапасын сақтауға және оны елдің орнықты даму қағидаттарына сәйкес келтіруге ықпал ететін «жасыл» қаржыландыру көздерімен байланысты экономика аспектілері жеткілікті шешілмегенін куәландырады. Сондай-ақ «жасыл» экономика, «жасыл» кредит, «жасыл» ойлау және басқа да сан қырлы ұғым ретінде қамтитын «жасыл» экономика мәселесі тиісті дәрежеде жандандырылмаған.

Зерттеу аясында қол жеткізілген тұжырымдар жалпы сипатқа ие және оларды талдау кезінде бар проблемаларды жою үшін қандай да бір қолданбалы шешімдер қабылдауды мақсат етпеген, жай ғана осы мәселе бойынша қазіргі жағдайды анықтап, осы саладағы ғылыми тәсілдердің заманауи тұжырымдамаларын қайта қарастыруды жалғастыруды мақсат еткен.

Тұжырымдама: Қазақстанда «жасыл» қаржыны дамыту және жеңілдік пен басқа да қолдаушы «жасыл» ынталандырулар арқылы мемлекеттің қолдауы «жасыл» экономиканың орнықты дамуын қамтамасыз етуге бағытталуы тиіс:

- «жасыл» қаржыны іске асырудың тиімді тетігін құру, бұл ретте жетекші шетелдер тәжірибесінің сабақтастық жақтарын пайдалана және өз мемлекетінің ұлттық мүмкіндіктерін ескере отырып;

- «жасыл» қаржыны дамытуды басқару жүйесін қалыптастыру және оны заңнамалық-нормативтік актілерде бекіту.

Kiлm сөздер: «жасыл» экономика, «жасыл» қаржыландыру, «жасыл» инвестициялар, «жасыл» жобалар, «жасыл» кредит, «жасыл» облигациялар және т.б.

\section{М.А. Уразгалиева, Н.К. Калаганова, О.И. Лыгина, И.А. Рыкова}

\section{Механизмы поддержки «зеленого» финансирования в мировой практике и в Казахстане}

\section{Аннотация}

Цель: Исследовать вопрос необходимости усиления роли «зеленого» финансирования в экономике Казахстана, изучить наиболее успешные примеры финансирования и реализации инструментов поддержки «зеленых» проектов более развитых стран. Соответственно, предметом исследования является финансирование «зеленой» экономики в мировой практике и в Казахстане.

Memoдbl: Применялись методы абстрактно-логического, системного и сравнительного анализа.

Результаты: В результате исследования оценено состояние развития «зеленого» финансирования в Казахстане и выявлены опыты передовых государств, где данный вопрос рассматривается как ключевая позиция глобального масштаба. Таким образом, в процессе анализа обозначились более продвинутые страны, такие как Китай, Корея, Великобритания, Канада и другие, которые добились определенных успехов в выпуске «зеленых» инструментов, осуществления производства электроэнергии за счет возобновляемых источников, переработки бытовых отходов и сокращения биоразлагаемых свалок и формирования адресных инвестиционных экологических фондов и т.д. Полученные результаты свидетельствуют о том, что на сегодняшний день в Казахстане недостаточно решены аспекты экономики, связанные с источниками «зеленого» финансирования, способствующие сохранению качества окружающей среды в условиях дефицита финансовых ресурсов и приведением его в соответствие с принципами устойчивого развития страны. Также не в должной мере активизирован вопрос «зеленой» экономики, который охватывает как многогранное понятие таких категорий, как «зеленая» экономика, «зеленый» кредит, «зеленое» мышление и ряд других.

Достигнутые выводы, обозначенные в рамках проведенного исследования, носят общий характер и при их анализе нами не ставилась цель выработать какие-либо прикладные решения по устранению существующих проблем, просто была поставлена задача - выяснить сегодняшнюю ситуацию по данной проблематике и продолжить переосмысление современных концепций научных подходов в данной сфере,

Bblвoдbl: Развитие «зеленых» финансов в Казахстане и поддержка государством с помощью льготных и других поддерживающих «зеленых» стимулов должны быть направлены на обеспечение устойчивого развития «зеленой» экономики через:

- создание эффективного механизма реализации «зеленых» финансов, при этом используя преемственные стороны опыта лидирующих зарубежных стран и с учетом национальных возможностей своего государства;

- формирование системы управления развитием «зеленых» финансов и закрепление ее в законодательнонормативных актах.

Ключевые слова: «зеленая» экономика, «зеленое» финансирование, «зеленые» инвестиции, «зеленые» проекты, «зеленый» кредит, «зеленые» облигации и т.д. 


\section{References}

Раков И.Д. Механизмы поддержки финансирования «зеленых» проектов: опыт стран [Текст] / И.Д. Раков // Актуальные проблемы экономики и права. - 2017. — № 2. - С. 67-82.

Жагыпарова А.О. МФЦА в выработке механизмов «зеленого» финансирования для модернизации казахстанской экономики [Текст] / А.О. Жагыпарова, Л.М. Сембиева, М. Таханова, М.Е. Карпицкая // Вестн. НАН РК. - 2019. - № 5. - С. 191-199.

Пантелева Н. Финансовый механизм предоставления инвестиционного кредитования в экономике Украины с участием международных финансовых институтов [Текст] / Н. Пантелева, М. Мищенко, К. Пантелева // Журн. НАН РК. - 2019. — № 6. - C. 141-151.

Kim, Hyoung-tae. System Architecture for Effective Green Finance in Korea [Text] / Hyoung-tae. Kim //Korea's Economy. - 2011. - № 27. - P. 18-24.

Покидаев Д. ПРООН одобрила поддержку 94 проектов модернизации ЖКХ в Казахстане / Д. Покидаев // Курсив - (https://kursiv.kz/news/ekonomika/2019-09/proon-odobrila-podderzhku-94-proektov-modernizacii-zhkkh-vkazakhstane)

Жандыбаев К. Как развивается «зеленая» экономика в Казахстане / К. Жандыбаев // STRATEGY 2050 обзорноаналитический портал — 2018. — (https://strategy2050.kz/ru/news/51441/).

Худякова Л.С. Саммит большой двадцатки: зеленый свет «зеленому» финансированию / Л.С. Худякова // ИМЭМОРАН. - 2016. - (https://www.imemo.ru/news/events/text/sammit-bolyshoy-dvadtsatki-zeleniy-svetzelenomu-finansirovaniyu? ret $=640$ )

«Зелёное» финансирование: есть шанс не опоздать. Евразийский банк развития. - 2019. — Green financing: there is a chance not to be late. — (https://eabr.org/press/news/zelyenoe-finansirovanie-est-shans-ne-opozdat)

Экологическое кредитование в странах Восточного партнерства. - ОЭСР. — 2014. — (http://www.oecd.org/ officialdocuments/publicdisplaydocumentpdf/? cote=ENV/EPOC/EAP (2014)7\&docLanguage $=$ Ru)

Как будут работать «зеленые» финансы в Казахстане. - Налоги в Казахстане. - 2019. (https://nalogikz.kz/docs/kak-budut-rabotat-zelenye-finansy-v-k.html)

Korea's Green Growth Experience: Process, Outcomes and Lessons. Learned. - Global Green Growth institute. 2015. - (https://www.Greengrowthknowledge.org/sites/default/files/downloads/resource/Koreas-Green-GrowthExperience_GGGI.pdf)

Unlocking investment to deliver Britain's low carbon future, Report by the Green Investment Bank Commission. Green Investment Bank Commission. - 2010. - (https://www.e3g.org/wp-content/uploads/ Unlocking_investment_to_deliver_Britains_low_carbon_future_Green_Investment_Bank_Commission_Report_June_2010 .pdf)

Policy perspectives Leveraging innovative public finance to scale up low-carbon investment. - OECD. — 2015. (http://www.Greeninvestmentbank.com/ media/25360/ar14-web-version-v2-final.pdf.)

Update on the design of the Green Investment Bank. H.M.Government. — GOV.UK. - 2011. - (https:// www.gov.uk/government/ uploads/system/uploads/attachment_data/file/ 31825/11-917-update-design-Greeninvestment-bank.pdf.)

Webb C. Canadian Institute for Environmental Law and Policy / C. Webb, Thomas C. Esakin // A Green Economy for Canada: Consulting with Canadians. — 2011. — (http://cielap.org/pdf/CIELAP_GreenEconomy.pdf)

Growing the middle class Morneau, W.F. — 2016. — (https://www.budget.gc.ca/2016/docs/plan/budget2016-en.pdf) 